\title{
EFL Teacher Professionalism and Identity: Between Local/Global ELT Tensions*
}

\section{Profesionalización e identidad del profesor de inglés: Entre tensiones locales/globales en la enseñanza del inglés}

\section{Julio César Torres-Rocha}

$\mathrm{He}$ is a teacher educator at Universidad Libre (Colombia) and currently a Doctoral Candidate in Education (TESOL) at University of Exeter (UK). He holds an MA in Research Methods in Applied Linguistics and ELT from Warwick University (UK) and an MA in Applied Linguistics to TELF from Universidad Distrital Francisco José de Caldas (Colombia). julio.torres@unilibre.edu.co

\section{Abstract}

This article of reflection considers socio-political issues such as linguistic im- perialism, native speakerism, English as an International language, and appropriate teaching methodologies, which are currently contentious issues in the ELT community. Framed within a critical approach of applied linguistics, these issues are addressed in three sections (global/ local tensions, teacher professional identity, and a new EFL professional identity) in order to argue that a dynamic, shifting, and multifaceted perspective of a globally-minded EFL teacher professional identity is needed so that Colombian EFL professionals can define or redefine their own identities in taking an informed and critical political stance.

* Received: November 23, 2018. Accepted: January 23, 2019

How to cite this article (APA 6th Edition):

Torres-Rocha, J. C. (2019). EFL teacher professionalism and identity: Between local/global ELT tensions. HOW, 26(1), 153-176. https://doi.org/10.19183/how.26.1.501

This article is licensed under a Creative Commons Attribution-NonCommercial-NoDerivatives 4.0 International License. License Deed can be consulted at https://creativecommons.org/ licenses/by-nc-nd/4.0/ 
Julio César Torres-Rocha

Keywords: EFL professionalism, professional identity, critical applied linguistics, English as an international language.

\section{Resumen}

Este artículo de reflexión considera elementos sociopolíticos como el imperialismo lingüístico, la ideología del hablante nativo, el inglés como lengua internacional y las metodologías de enseñanza apropiadas; aspectos que son controversiales en la comunidad ELT. Dentro del marco de la Lingüística Aplicada Crítica, estos elementos se discuten en tres secciones (tensiones globales/locales, identidad profesional del docente y una identidad profesional EFL nueva) para argumentar que se necesita una perspectiva dinámica, multifacética y cambiante de la identidad local y global del profesor de inglés, para que, de esta manera, los profesionales del inglés como lengua extranjera puedan definir o redefinir sus identidades tomando un posición política informada y crítica.

Palabras clave: profesionalismo EFL, identidad profesional, lingüística aplicada crítica, inglés como lengua internacional.

\section{Introduction}

Within education, newly emerging professionals in occupations such as TESOL (Teaching English to Speakers of Other Languages), ESL (English as a Second Language), and EFL (English as a Foreign Language) had shared a disadvantaged status until recently. Malley (1992) stated that TESOL teachers are not 'professionals' in quite the same sense as doctors or lawyers. The president of TESOL, Nunan (1999), declared that even with a number of committed and active institutions and associations, TESOL still has a weak disciplinary basis and low standards of practice and certification. However, this perspective has now changed because English language teachers have gained professional status by

154 participating in and contributing to the field (Lorimer \& Schulte, 2011). English Language Teaching (ELT) is regarded as a career in a field of educational specialization, which requires a specialized knowledge obtained through both academic study and practical experience. It is now a field of work wherein membership is based on entry requirements and standards (Richards, 2008).

Are EFL teachers in Colombia regarded as professionals? It can be said that they can be given such a status, and therefore a particular professional identity, 
EFL Teacher Professionalism and Identity: Between Local/Global ELT Tensions

if, besides being qualified, experienced, and up-dated ELT specialists, they work to become practitioners who are aware that any teaching context is situated on both global and local scales simultaneously. Guerrero-Nieto and Meadows (2015) and Varghese (2011) refer to this as a global professional identity. In the same way, it has to be recognized that local/global tensions place EFL teachers at a disadvantage as non-native English speaking teachers (NNESTs). It may happen since global perspectives as well as local views on specific issues of English language teaching have become conflicting among scholars who have worked for EFL professionalism in Colombia in the last decades. Issues such as what English to teach, what culture to emphasise, and what methods to follow undoubtedly are now priorities for English language teachers' practices, and therefore for their professional identity development at the local level.

\section{Global/Local ELT Tensions and EFL Professionalism}

The global perspective of ELT has favoured the Western views of "standard" languages (linguistic imperialism) as the mandate that has to be followed by the colonies and neo-colonies in the peripheral countries. Therefore, English as a global language (Crystal, 2012), inner circle cultures (Kachru, 1992), and communicative language methods as the most effective way of teaching the language have become the global trends in the ELT world. It is important to acknowledge that "the English language, in its long march to its current global status, was aided and abetted by the colonialist and imperialist projects that trampled upon the political, cultural and political heritage of millions of people around the globe." (Kumaravadivelu, 2006, p. 539) Together with it, the native speaker of English (NSE) has been established as the authority, not only in linguistic terms but also in cultural and pedagogical terms as universal perspectives in English language teaching.

External pressures such as neo-colonialism, globalization, and neoliberal policies have impacted the development of ELT (Holliday, 2005; Pennycook, 2001; Phillipson, 1992). According to Bourdieu (as cited in Phillipson, 2004), U.S. norms seem to be the global default since globalization fundamentally means Americanization: 
Globalization serves as a password, a watchword, while in effect it is the legitimatory mask of a policy aiming to universalize particular interests and the particular tradition of the economically and politically dominant powers, above all the United States. It aims to extend to the entire world the economic and cultural model that favours these powers most, while simultaneously presenting it as a norm, a requirement, and a fatality, a universal destiny, in such a manner as to obtain adherence or, at the least, universal resignation. (p. 84)

According to Lin and Martin (2005), a key paradox is the widespread demand for more English, although English does not serve all equally well. Within differing country reports, the pattern is of a disappearance of 'linguistic local' and the one-sided pursuit of the 'linguistic global' (p. 9). Examples of this situation in India, Singapore, and even China are presented in order to explain how inadequate educational policy leads to the perpetuation of social inequalities in these and other African and Asian countries. Lin and Martin (2005) argue that the global proliferation of English is a precondition for the success of corporate globalization; therefore, how and why the language is learned and used ought to be a major concern in the neo-imperial age in which we now live. The interaction of globalisation forces and neoliberal policies with language teacher education is now eminent, evidencing the geopolitics of teaching English as an international language.

Nowadays, a globally-minded identity of professional ELT practitioners is necessary due to political, economic, cultural and market factors that have positioned Western epistemologies in ELT rather than those of EFL local communities. Global perspectives have influenced dramatically ELT local perspectives and have impacted EFL teacher professional identities. The field of ELT has become a global phenomenon. The neoliberal flows in education 156 have placed English and English language teachers in a position of diverse levels of professionalism and therefore in the need to assume different professional identities in order to be able to respond to the high demand in increasingly complex national and international scenarios. Native and non-native English language teachers are part of the working force used everywhere in the globe, regardless of their qualifications, experience, or previous training. ELT professionalism has been constructed based on power and knowledge differentials 
EFL Teacher Professionalism and Identity: Between Local/Global ELT Tensions

that privilege the inner countries and native speakers and masks the subordination of peripheral countries and non-native speakers. All the above mentioned factors might mark the origin of conflicts and tensions in the ELT community.

Globalization has exposed contradictions or tensions and opened a space for ELT professionals to be able to challenge the conventional boundaries of authority and legitimacy in terms of what content to teach, who will teach it and how English should be taught (Kachru, 1992). For example, ELT scholarship in the critical tradition (Phillipson, 1992) has illustrated the historical legacy of colonialism, which marginalizes non-native English speaking teachers (NNESTs) for not meeting the British Australian North American (BANA) cultural and linguistic profile. Due to these external international pressures, certain influences and forces arise and cause local communities to feel ill at ease, worried or discontent. Native speaker teachers represent the authoritative knowledge of English and learning methods; Standard English varieties (British and American) are taught around the globe.

The global spread of ELT now means that the majority of English teachers worldwide are NNESTs (Canagarajah, 1999; Park, 2012; Seidlhofer, 2005). In spite of this fact, native speakerism, a pervasive ideology within ELT, is characterized by the belief that 'native-speaker' teachers represent a 'Western culture,' associated with the ideals of the English language and of English language teaching methodology (Holliday, 2005), which seems to be the norm in different settings where English is taught as a second language (ESL) or foreign language (EFL). The native speaker fallacy, which is the notion that the ideal English teacher is the native speaker of that language (Phillipson, 1992), has been a global perception in many places until research in this area questioned this still prevalent belief. Fundamental constructs such as the legitimacy and authority of native speakers are now being challenged and redefined from multiple viewpoints within the profession and across the globe. However, this ideology has privileged certain groups and harmed NNESTs, not only in economic and political terms but also in issues related to their professional identity and confidence.

Colonialism in the pedagogy and didactics of ELT has not been out of the question in regard to methods used in the field. Communicative language teaching (CLT), task-based approach and content-based learning have become 
fashionable trends promoted from the inner circle countries in the last three decades. However, according to Copland, Garton, and Burns (2014), "CLT is a pedagogical approach developed in Western countries to teach adults in small, well-equipped classrooms" (p. 740); however, it may not be appropriate for teaching large groups of students in classrooms where resources are limited. Furthermore, as EFL teachers may receive only basic training in the underpinning theory and practical applications, they might struggle to implement it effectively. Also, Kumaravadivelu (2006) has demonstrated that "not a single method is universal and therefore can serve all needs, contexts, and learning or cognitive styles" (p. 69). He has challenged current ELT methods like CLT based on research as to its efficacy that casts serious doubts, and suggested entering in a post-method era in which some orienting principles should be applied to find a context-sensitive pedagogy that best suits a particular population and context.

These principles are: authenticity, acceptability, and adaptability. Kumaravadivelu (2006) defines authenticity as a feature of a method that should promote serious engagement with meaningful negotiation, interpretation, and expression in the language classroom; acceptability, a widely accepted view of a method; and adaptability as a principle that can be applied to suit various contexts of language teaching across the world and time. It has become increasingly apparent that CLT does not meet these criteria in a lot of contexts in the globe. Holliday (2005) suggests a plan for designing an appropriate methodology, a modified CLT that is sensitive to different sociocultural demands. CLT, task-based approach, or content-based learning has not been easily adaptable to diverse settings, or teachers do not have a sense of plausibility for these methods in several local contexts.

Together with language and who that language belongs to, the issue of 158 whose culture to teach and what perspective of culture should be taught represent other contentious aspects of the global interests in ELT. From the cultural neo-colonial perspective that goes hand in hand with linguistic imperialism to the essentialist perspective of one language, one culture and one nation, the ELT professional has been moving from a practical laissez faire attitude to more critical positions towards the teaching of English, in which world Englishes, intercultural education, and multilingual and pluricultural competences are 
EFL Teacher Professionalism and Identity: Between Local/Global ELT Tensions

fomented. Teachers of English as an International Language (EIL) should start with an understanding of the various ways culture can be related to language.

Sharifian (2009) describes 'cultural conceptualizations' as schemas and cultural metaphors that 'emerge from the interactions between the members of a cultural group' (p. 242). EIL involves, by definition, speakers negotiating communication across different cultural conceptualizations (p. 246). This emergent character implies that EIL teachers and learners are agents of transculturation, not just the subjects of acculturation. McKay (2002) lays out a framework for understanding how EIL learners need knowledge of diverse cultures and, besides understanding other cultures, helps learners see the distinctiveness of their own cultures (p. 83). That is to say, understanding the general nature of cultural difference is more important to communication than mastering the cultural specifics of a given Inner Circle country, or the cultural specifics of any particular interlocutor (Dogancay-Aktuna \& Hardman, 2012).

Nonetheless, cultural differences are not 'neutral' but embody differences in access to a variety of types of cultural capital (economic, political, social, etc.). Kubota (2004) critiques 'liberal multiculturalism' as uninterested in the political nature of cultural difference and for essentializing cultures as static. Therefore, EIL teachers do not need specific knowledge of a particular culture 'transmitted' to them, but an understanding of how culture is continually generated, reproduced, and changing in socio-political contexts. For years, native speakers and their cultures have been the centre of attention; it is about time that EFL teachers recognize that the teaching of English does not imply a monolithic perspective of language and culture of the inner countries, but rather a transcultural perspective of intercultural communication, that is to say, the development of an intercultural communicative competence in learners, teachers, and teacher-educators.

\section{Professional English Language Teacher Identity and Professionalism}

The global concerns in ELT mentioned above and the search for more pertinent approaches to EFL policies in local realities are part of professionalism in ELT and teacher identities in many peripheral countries; this is so 
Julio César Torres-Rocha

because English language teachers' subject area, their identity as NS or NNS, their position towards cultures, and the language teaching methods used are intrinsically related to what defines Teacher Professional Identity (TPI). Interest in TPI in the ELT field is fairly recent (Liu \& Xu, 2011; Norton \& Early, 2011; Tsui, 2007). In fact, it can be said that global and local tensions are embodied in the sociocultural self of teachers and their practices, therefore, in their professional identity.

A review of literature about language teacher identity (Liu \& Xu, 2011) shows that three main themes have been widely discussed. The first is the relationship between teachers' linguistic positions and professional identity. These studies explore how the dichotomy of NS/NNS has burdened NNS teachers with feelings of inferiority, thus prompting them to question their competence as legitimate language education professionals (Jenkins, 2005; Park, 2012; Pavlenko, 2003). The second theme explores conflicts between social and professional identities (Varghese et al., 2005) and posits that teachers' professional identities have been undermined by their gender, race, and ethnicity. These studies defend a holistic, dynamic view of understanding how the negotiations between teachers and the wider socio-cultural contexts have shaped TPI. The third theme explores how teacher identity is mediated in educational reforms (Liu \& Xu, 2011; Tsui, 2007), and how the mediating role of power relationships in the process of identity formation exerts a strong influence.

According to Lasky (2005), TPI is how teachers define their professional roles. This dynamic construct (Barrett, 2008; Varghese et al, 2005) has been shown to have significant effects on teachers' development and performance. From a sociocultural perspective, even learning to teach is primarily a process of professional identity construction rather than knowledge acquisition (Nguyen, 2008; Varghese et al., 2005). Therefore, the extent to which teacher education 160 leads to positive changes can be largely determined by the identities that teachers bring to contexts and how they are reconstructed during teacher education (Singh \& Richards, 2006, in Abednia, 2012).

An essential part in the construction of professional identity is what any teacher does in everyday practice when the teacher assumes his/her practice as critical reflective practice (Kumaravadivelu, 1999). This way, teachers can inform their practices and consequently modify beliefs, conceptions and personal 
EFL Teacher Professionalism and Identity: Between Local/Global ELT Tensions

theories that are used as teachers' assumptions in their practice. Borg (2006) framed it in what is called Teacher Cognition, that is to say, how teachers' experiences, beliefs, thoughts and thinking processes shape their understanding of teaching and their classroom practices, and therefore their professional identities. Teacher cognition is, besides practical knowledge, pedagogic content knowledge, and personal theories of teaching, which are very much concerned with teachers' personal and 'situated' approaches to teaching (Richards, 2008, p. 167). Therefore, critical reflective practice (Moncada, 2009), teacher cognitions, and situated EFL methods (Mora, Trejo, \& Roux, 2014) as part of Colombian EFL teacher identity, should be the starting point to build a contextualised construct of professionalism.

Wenger (1998) identifies five dimensions of identity, which are apposite when thinking about professional identity; they embrace the most relevant aspects of teacher professional identity presented up to this point. These are: (1) identity as negotiated experiences where teachers define who they are by the ways they experience their own selves through participation as well as the way they and others reify themselves. (2) identity as community membership where they define who they are by the familiar and the unfamiliar; (3) identity as learning trajectory where they define who they are by where they have been and where they are going; (4) identity as a nexus of multi membership where they define who they are by the ways they reconcile their various forms of identity into one identity; and (5) identity as a relation between the local and the global where they define who they are by negotiating local ways of belonging to broader constellations and manifesting broader styles and discourses.

These five dimensions of identity have application in developing "a revised view of professional identity for teachers as they address the social, cultural and political (macro and micro, individual and group) aspects of identity formation" (Sach, 2001, p. 154). In the same track of thought, the view of professional identity reconstructed by many personal, social and emotional experiences has an important effect on the teaching expertise of several EFL teachers who commit themselves to the profession (Ubaque \& Castañeda-Peña, 2017).

This TPI, which has been studied and researched within broader perspectives, should now focus on the complexities of globally minded professionals who not only reconcile global and local tensions but also deal with internal 
Julio César Torres-Rocha

conflicting dilemmas and challenges present in their current context-sensitive pedagogies and practices. The next session will intend to address how going from colonial to de-colonial perspectives, from professionality to professionalism and departing from a construction of a strong TPI, a more critical and globally minded professional of EFL can be envisioned.

\section{Local/Global ELT Tensions and EFL Professionalism}

Besides these "external" factors mentioned above, some internal factors are part of the complex milieu of ELT professionalism in peripheral countries like Colombia at present. For instance, in the last decade, through various foreign language policies, The Colombian Ministry of Education (MEN in Spanish) has progressively and strategically been reducing the concept of being bilingual from a number of working languages to considering only English and Spanish, leaving aside other Colombian languages and transforming the Colombian language paradigm into a form of English mono-lingualism. According to Escobar (2013) and Usma (2009), these distortions of the concept of bilingual education can have negative implications in cognitive, cultural, linguistic and identity interrelationships. In other words, standardization, homogenization, and simplification of the notion of language are being fostered in the quest for power and control, consequently overthrowing the value of local knowledge, difference, and diversity. Consequently, a new EFL teacher is needed to try to balance the external and the internal factors that affect the teaching of English in Colombia.

Why is a globally minded identity necessary as part of the TPI presented above? In the ELT field, the increasing interaction between ELT communities

162 around the world, as well as the recognition of traditional epistemologies and ways of teaching that English language professionals use in diverse contexts are day after day more evident. Nowadays, ELT professionals establish contact with one another around the globe, through transnational conversations. However, they do not establish symmetrical dialogues because there are forces of colonialism and neo-colonialism that permeate international collegial interactions. The preponderance of native speakers, the symbolic power of English, and the structures of knowledge that privilege inner circle research production are 
EFL Teacher Professionalism and Identity: Between Local/Global ELT Tensions

some of these forces or discourses that mediate ELT professionalism at the local and global levels.

ELT discourses of professionalism and professional identity, it is claimed, hide processes of marginalization and discrimination because they come from Eurocentric or Imperialistic perspectives (Adams, 2012). According to Adams (2012), in the postmodern world, a unified construct of the concept of professionalism does not only require a set of practices, a type of expertise or a disciplinary mechanism, but an episteme that enables teachers to analyse professionalism as a broad discursive formation - "other" epistemological configuration, not the prevailing epistemologies associated with colonial or post-colonial legacies. As Larson (1990) suggested, "a theory of professions should be centrally concerned with the conditions under which knowledge is produced and applied in ways that make a difference for the life of "others", the historically neglected local indigenous peoples or third world inhabitants" (p. 32). In the local context, de Mejia (2011) concurs with this idea about the disregard of local knowledge and expertise when informing language policy perspectives, as well as when excluding other types of bilingualism (including indigenous languages or creole varieties) in Colombia.

Castro-Gomez (2007) and Mignolo (2009) say that, although colonialism and modernism seem to have disappeared in previous centuries to give birth to post-colonialism and postmodernism, hegemonic and Eurocentric perspectives remain deeply ingrained in peripheral countries. "Geopolitics of knowledge goes hand in hand with geopolitics of knowing" (Mignolo, 2009, p. 2), but by whom and when, why and where is knowledge generated are questions that intend to shift the attention from the current loci of enunciation, the eurocentred epistemologies, to the "other" epistemologies of the local communities.

The issues of colonial legacy and the native speaker bias in ELT are critical matters in local ELT communities and/or organisations. The global native speakerism ideology (Holliday, 2005) and the weak confidence of the local NNS teachers impact the identity of professional EFL teachers in different ways. For instance, the deficit perspective (Jenkins, 2006) of their language competence disempowers EFL teachers who do not reach the C2 level of English according to the CEF (Common European Framework) and marginalises them, causing them to go through audits, targets, performance reviews and leading to the 
de-professionalization (Evetts, 2012) of local English teachers. This might happen due to the vision of professionalism "from above", institutionalised by means of top-down policies that establish de-contextualised standards, universal methods, and culturally biased materials in particular settings (Guerrero-Nieto \& Meadows, 2015; Gonzalez, 2007), and also due to the imposition from external authorities to promote organisational control and subsequently undermining local professionalism, thus replacing it with external values or norms, as stated by Evetts (2012) and Gonzalez (2007). This is what has been going on in the local context like Colombia where English is taught as a foreign language with foreign materials and foreign teaching approaches. De Mejia (2016) states that researchers in Colombia have recently questioned the common practice of adopting pedagogical systems which have been designed and implemented in very different contexts.

In Colombia and other peripheral countries foreign approaches to teaching English have been adopted. In doing so, EFL teachers have faced difficult adaptation processes with multitude challenges. For instance, a potential challenge for teachers to implement CLT has to do with the level of English they require. Teachers' low proficiency level, or their lack of confidence in their ability, is identified in the literature (Cárdenas \& Chaves, 2013; Kuchah, 2009; Littlewood, 2007). Many teachers believe that CLT demands particular classroom procedures, such as teaching in the target language, which causes anxiety and leads to teachers' questioning their competence, particularly their speaking and listening skills, as reported by Kuchah (2009). In Colombia, this is particularly true according to studies on EFL high school teachers (Gonzalez, 2010; Torres-Rocha, 2017) who reported different levels of proficiency.

Torres-Rocha (2017) also reported teachers' mixed emotions towards the language requirements associated with a national bilingual programme in 164 Colombia. This showed how these demands have affected their professional identities in various ways. These issues of methodology, language requirements, and imposed language policies reflect the hegemonic perspectives of inner circle countries and the legacy of colonial times still present in peripheral countries like Colombia. Applied linguists, scholars, and teacher-educators who regard them from a critical position are now problematizing these and many other "givens" of the Colombian ELT world (Bonilla \& Tejada-Sanchez, 2016). 
EFL Teacher Professionalism and Identity: Between Local/Global ELT Tensions

Researchers have evidenced the need for teachers to move from their narrow technical role to a more political stance that will extend their professionalism as English educators to a broader political activist role, the role of educational activist (Apple, 2012).

Critical perspectives that challenge hegemonic views and power structures benefit language teacher education across global contexts. Specifically, Critical Applied Linguistics (CALx) has helped teachers develop a critical professional stance by considering the many external and internal factors that affect them in their particular contexts (Guerrero-Nieto \& Meadows, 2015). CALx is a relatively new field of social sciences, education, and applied linguistics. However, it is necessary to highlight important contributions and sketch the peculiar characteristics of this perspective. A place to start is the politics of knowledge that is concerned with the workings of power, especially in applied linguistics and language policy in a world where English seems to be imposed all around, regardless of its utility, relevance, and potentially harmful symbolic power (Pennycook, 2001). Closely related to this issue is a political understanding of language and its extremely powerful representation of imposed realities that fight against each other in global and local contexts. I am referring to the unstoppable spread of English and the dramatic disappearance of indigenous languages all around the world. Also, the epistemologies of the western colonisers opposed to the neglected worldviews of post-colonialism; decolonialisation is a concern in the same line of thought.

In the same way that CALx regards ideology as the main focus of inequality, marginalisation, racism (as part of exclusion in the ELT area), and externally imposed perspectives of professionalism can also be seen as part of the exclusion within a "sophisticated understanding of professionalism" (Wilson et al., 2013). Nevertheless, I would argue that an internally determined "awareness of the nature of professional expertise, quality, conduct and ethics" comes from a personal experience of professionalism as a part of teachers' self-identity, relevant to all aspects of their lives. Therefore, I believe that internal teachers' cognitions (Borg, 2006) are more influential than external factors implicated in the enactment of professionalism when it comes to the process of teaching and learning English and the development of critical professional identity. 
Julio César Torres-Rocha

It does not really matter which authorities or ministries create or determine the frameworks for professionals of teaching. These imposed frameworks are complied with by institutions, regardless of teachers' previous experiences, conceptions, and practices which are actually the elements that exert the enactment of professionalism in local contexts. In this regard, Sachs (as cited in Evans \& Waring, 2014) affirmed, "Professional standards for teachers and what it means to be a teacher cannot be imposed, they need to be owned and overseen by the profession itself" (p. 6). I would argue, in the next session that a new professional identity in Colombia is arising from the current socio-political tensions and collective awareness; a situation that represents the emergence of critical, reflective, and political ELT professionals.

\section{Towards a New EFL Teachers' Professional Identity in Colombia}

In this century, for EFL teachers, expert knowledge of the subject, of pedagogy and students or the compliance with general professional standards is not enough; developing a strong professional identity as an English language practitioner by raising a thorough awareness of the socio-political factor of ELT at internal and external levels is also necessary. Horn (2016) states that profession, professionality, and professionalism might be "about the formation of a professional identity" (p. 130). Therefore, EFL teacher educators should have a strong professional identity in order to pass that on to student-teachers in "Licenciatura" programmes. This could be done by means of coherent curricular proposals that take into account EFL teacher educators' experiences, beliefs, and practices obtained throughout their professional development.

Mainstream educational research recognises the impact of teacher cognition 166 on teachers' professional lives. According to Borg (2006) teacher cognition is an inclusive term referring to the complex, practically oriented, personalised, and context-sensitive network of knowledge, thoughts, and beliefs that language teachers draw on in their work. Borg's work examines what teachers think, know, or believe in relation to any aspects of their work and the relationship between cognition and practices. If EFL teachers identify, understand, and modify their cognitions, for their part, they will be able to respond to the needs of a globally minded professional and locally aware practitioner. 
EFL Teacher Professionalism and Identity: Between Local/Global ELT Tensions

As far as I am concerned, only when interaction of cognition and practice is understood, can EFL teachers then achieve a critical professional identity. The externally imposed standards can be examined, and external and internal perceptions of professionalism can be reconciled by means of a dialogic approach in which authorities, scholars, and teachers come to agreements on situated professional frameworks which are the product of a thorough understanding of local professional identities and professionality. However, the MEN (2017) established the characteristics of the Licenciatura programmes and a profile for teacher-educators that might not meet the experience, beliefs, practices, and roles that they currently have at universities in Colombia.

Transformation comes from within, therefore, following Bronfenbrenner (1979)'s ecological theory of human development, teachers can move from an internal conception of professionalism (micro and meso dimensions) or professionality to an external development and exercise of professionalism (exo and macro dimensions) in which micro-political factors, integration of knowledge, and professional development orientation can occur in a situated manner. This transformation cannot be established by simply issuing a decree (No. 18583, MEN, 2017) in a top-down way.

In other words, following Evans's (2011) view of professionality (personal or individual sphere) and professionalism (collective sphere), if professional development essentially involves the advancement of individuals along the professionality continuum towards the 'extended' end, then it is certainly approaching professionality a way to start constructing teacher professional identity. Consequently, professional identity can function as the lens through which professionalism can be further explored and constructed in local realities (see also Evans, 2014), rather than imposed "from above" (Evetts, 2012) through managerial use or organisational professionalism to promote only organisational control.

Through a journey of professionalization, the ELT global community has constructed frameworks of relationships that would enable an effective negotiation of practices and discourses between the different professional communities, which facilitate more constructive teacher identities (Canagarajah, 2012). A new global professional identity for a language teacher practitioner entails, besides the identification of where their cognitions come from, a critical view of what ELT professionalism is in their own context, an awareness of 
the geopolitics of the teaching of English as an international language, and an ongoing search for the most appropriate methods of language teaching in line with the context and situation of practice. In short, a dynamic construction of identities as something complex, changing and multifaceted (Norton, 1997, Beijaard, Meijer, \& Verloop, 2004) will lead to a pluralistic conception of professionalism.

Canagarajah (2014) and Dogancay-Aktuna and Hardman (2012) framed new EFL/ESL teachers in the development of an EIL Teacher model where English is conceived as a "form of practice" (Canagarajah, 2014; Pennycook, 2010) and a "mobile resource" (Blommaert, 2010). Canagarajah (2014) considers the engagement with diverse languages and cultures as contributing to the language awareness and negotiation strategies of the students. He says that EFL teachers have to adopt a different disposition when teaching students for the unpredictable contexts of globalization. They have to become learners with their students-learning new varieties of English, new genres of communication, and new modes of negotiating language diversity.

According to Escobar (2013), identity is closely and directly related to discourse since "this is how individuals act and interact, position themselves and are positioned in a social place, a way of being in the world, and thus a way to form and transform identities" (p. 45). By using power and control, discourses are maintained and perpetuated, as stated by Bernstein (as cited in Escobar, 2013). Relations of power create, justify, and reproduce limits between different group categories: gender, social class, nationality, etc. Escobar (2013) also argued that, in Colombia, this is the way foreign language policies, as identity-forming discourses, have nurtured EFL teacher identity as NNS, which "would naturally accept processes of exclusion, unequal social structures and thus, unfair educational conditions governed by foreign intentions" (p. 46).

It is important to keep on "exploring these issues for NNESTs and their professional identities in the ELT field because this can benefit our understanding of language teacher education for the global society" (Guerrero-Nieto \& Meadows, 2015, p. 26) as well as for the local communities wherein complex realities are yet to be discovered and understood. Further research is necessary to establish the new venues of research regarding language teacher professional identities (González et al., 2002; González, 2007). According to Varghese et al. 
EFL Teacher Professionalism and Identity: Between Local/Global ELT Tensions

(2005), distinguishing between researching on teachers' professional identity in general and language teacher identity is also crucial. In the latter, sociocultural, sociolinguistic, and ethnic considerations take a central stage. Varghese et al. (2005) summarise the most important issues in identity research as follows: first, identity is multiple, shifting and in conflict; second, identity is crucially related to social, cultural, and political context; and, third, identity is being constructed, maintained and negotiated primarily through discourse.

\section{Conclusions}

I would like to suggest actions to foster the development of a strong professional identity not only in EFL student-teachers, but also in EFL teacher educators. First, nurturing a strong contextually constructed EFL teacher identity, in Colombia and other EFL settings, can develop new perspectives on situated professionalism. This can be done by recognising local epistemologies that characterise teacher learning, reconcile global and local in a locally responsive approach to EFL teaching, and in the end, decolonise language, practices, and education. Other researchers in Colombia have proposed similar agendas, regarding teacher professional development. They suggest three actions: first action, giving teachers' agency and voice in construction of their own professional profiles, their development process, so that they will "fulfil their professional needs of expression of self-esteem, sense of belonging to a community, and self-realization" (Maslow, 1998; González et al., 2002; González, 2007).

Second, celebrating local knowledge implies a "process of negotiating dominant discourses and engaging in an ongoing construction of relevant knowledge in the context of our history and social practice" (Canagarajah, 2005, p. 13). Third and final action, deconstructing established knowledge to understand its local shaping and reconstructing local knowledge for actual needs. González (2007) argues that making the reflective interpretation of established knowledge for local needs is necessary; also, accommodating local knowledge to current conditions so that it can be relevant for other settings beyond local needs. This might as well be true for rural settings in Colombia, as suggested by Bonilla \& Cruz-Arcila (2014), where EFL teaching and learning processes become more complex due to the particular sociocultural factors involved in such endeavour. 
Julio César Torres-Rocha

All the above suggestions will be plausible within a "democratic approach to professionalism" in the local context. In fact, this is the big challenge for most EFL communities in peripheral countries like Colombia because democratic professionalism and its associated "activist identity" (Sachs, 2001; 2003) require stronger professional bodies and associations (Whitty, 2006). This can be done if teachers and teacher-educators, who are themselves scholarly and politically prepared, work in an open and meaningful way with stakeholders as well as with colleagues in collaborative learning groups (self-study groups) for the benefit of learners.

Finally, I would suggest future action and reflection on fomenting professional identity construction of teachers in Colombia in Teacher Education programmes. In this way, they will be able to take responsibility for initiating informed processes of change, bearing in mind local realities and global concerns (De Mejia, 2016). EFL practitioners have to face informed decisions, and construct a strong professional identity and agency that will help them face their responsibility as individuals, rather than having to comply with an accountability culture (Biesta, 2004) imposed by the state through the MEN and the foreign language policies. With this reflective article on professionalism, local and global tensions in the ELT field, and EFL teacher professional identity, I want to contribute to the current concerns and expectation of Colombian scholars, especially teacher-educators like me, with the intention to encourage new possibilities of research and professional learning from a political stance and local knowledge creation pertaining to our educative contexts.

\section{References}

Abednia, A. (2012). Teachers' professional identity: Contributions of a critical EFL teacher education course in Iran. Teaching and Teacher Education, 28(5), 706-717.

Adams, K. F. (2012). The discursive construction of professionalism: An episteme of the 21st century. Ephemera: Theory and Politics in Organization, 12(3), 327-343.

Apple, M. W. (2012). Can education change society? New York: Routledge. 
EFL Teacher Professionalism and Identity: Between Local/Global ELT Tensions

Beijaard, D., Meijer, P., \& Verloop, N. (2004). Reconsidering research on teachers' professional identity. Teaching and Teacher Education, 20(2), 107-128.

Biesta, G. J. (2004). Education, accountability, and the ethical demand: Can the democratic potential of accountability be regained? Educational Theory, 54(3), 233-250.

Blommaert, J. (2010). The sociolinguistics of globalization. New York. Cambridge University Press.

Bonilla, S. X., \& Cruz-Arcila, F. (2014). Critical Socio-Cultural Elements of the Intercultural Endeavour of English Teaching in Colombian Rural Areas. Profile: Issues in Teachers' Professional Development, 16(2), 117-133.

Borg, S. (2006). Teacher cognition and language education. London: Continuum.

Bronfenbrenner, U. (1979). The ecology of human development. Cambridge, MA: Harvard University Press.

Canagarajah, A. S. (1999). Interrogating the "native speaker fallacy": Non-linguistic roots, non-pedagogical results. Non-native educators in English language teaching, 77-92.

Canagarajah, A. S. (2005). Reconstructing local knowledge, reconfiguring language studies. Reclaiming the Local in Language Policy and Practice, 3-24.

Canagarajah, A. S. (2012). Teacher development in a global profession: An autoethnography. TESOL Quarterly, 46(2), 258-279.

Canagarajah, A. S. (2014). In search of a new paradigm for teaching English as an international language. TESOL Journal, 5(4), 767-785.

Cárdenas, R., \& Chaves, O. (2013). English Teaching in Cali. Teachers' Proficiency Level Described. Lenguaje, 41(2), 325-352.

Castro-Gomez, S. (2007). The missing chapter of the Empire: Postmodern re-organization of coloniality and post-Fordist capitalism. Cultural Studies, $21(23), 428-448$.

Copland, F., Garton, S., \& Burns, A. (2014). Challenges in teaching English to young learners: Global perspectives and local realities. TESOL Quarterly, 48(4), 738-762. 
Julio César Torres-Rocha

Crystal, D. (2012). English as a global language. Cambridge \& New York: Cambridge University Press.

De-Mejia, A. M. (2011). The National Bilingual Programme in Colombia: Imposition or opportunity? Apples-Journal of Applied Language Studies.

Dogancay-Aktuna, S., \& Hardman, J. (2012). Teacher education for EIL: Working toward a situated meta-praxis. In A. Matsuda (Ed.), Principles and practices of teaching English as an international language (Vol. 25) (pp. 103-120). Bristol: Multilingual Matters.

Escobar, W. (2013). Identity-forming discourses: A critical discourse analysis on policy making processes concerning English language teaching in Colombia. Profile: Issues in Teachers' Professional Development, 15(1), 45-60.

Evans, C., \& Waring, M. (2014). Understanding pedagogy: Developing a critical approach to teaching and learning. London: Routledge.

Evans, L. (2011). The 'shape' of teacher professionalism in England: Professional standards, performance management, professional development and the changes proposed in the 2010 White paper. British Educational Journal, 37(5), 851-870.

Evetts, J. (2012). Professionalism in Turbulent times: Changes, challenges and opportunities. Propel International Conference, Stirling, Scotland, 9-11 May 2012.

González, A. (2007). Professional development of EFL teachers in Colombia: Between colonial and local practices. Íkala, Revista de Lenguaje y Cultura, 12(18), 309-331.

González, A. (2010). English and English teaching in Colombia: Tensions and possibilities in the expanding circle. In A. Kilpatric, The Routledge bandbook 172 of world Englishes (pp. 354-374). London, New York: Routledge.

González, A., Montoya, C., \& Sierra, N. (2002). What do EFL teachers seek in professional development programs? Voices from teachers. Íkala, Revista de Lenguaje y Cultura, 8(14), 153-172.

Guerrero-Nieto, C., \& Meadows, B. (2015). Global professional identity in deterretorialized spaces: A case study of a critical dialogue between expert and novice nonnative English speaker teachers. Profile: Issues in Teachers' Professional Development, 17(2), 13-27. 
EFL Teacher Professionalism and Identity: Between Local/Global ELT Tensions

Holliday, A. (2005). The struggle to teach English as an international language. Oxford: Oxford University Press.

Horn, K. P. (2016). Profession, professionalization, professionality, professionalism historical and systematic remarks using the example of German teacher education. British Journal of Religious Education, 38(2), 130-140.

Jenkins, J. (2005). Implementing an international approach to English pronunciation: The role of teacher attitudes and identity. TESOL Quarterly, 39(3), 535-543.

Jenkins, J. (2006). Points of view and blind spots: ELF and SLA. International Journal of Applied Linguistics, 16(2), 137.

Kachru, B. B. (1992). Teaching world Englishes. The other tongue: English across cultures. USA: Illinois Press.

Kubota, R. (2004). Critical multiculturalism and second language education. In B. Norton and K. Toohey (Eds.), Critical Pedagogies and Language Learning (pp. 30-52). Cambridge: Cambridge University Press.

Kuchah, K. (2009). Early bilingualism in Cameroon: Where politics and education meet. In J. Enever, J. Moon, \& U. Raman (Eds.), Young Learner English Language Policy and Implementation. Reading (pp. 87-94). UK: Garnet Education.

Kumaravadivelu, B. (1999). Theorising practice, practising theory: The role of critical classroom observation. Theory in Language Teacher Education, 33-45.

Kumaravadivelu, B. (2006). TESOL methods: Changing tracks, challenging trends. TESOL Quarterly, 40(1), 59-81.

Kumaravadivelu, B. (2012). Language teacher education for a global society: A modular model for knowing, analyzing, recognizing, doing, and seeing. London: Routledge.

Larson, M.S. (1990) 'In the matter of experts and professionals, or how impossible it is to leave nothing unsaid'. In R. Torstendahl \& M. Burrage (Eds.), The formation of professions: Knowledge, state and strategy (pp. 24-50). London: Sage.

Lasky, S. (2005). A sociocultural approach to understanding teacher identity, agency and professional vulnerability in a context of secondary school reform. Teaching and Teacher Education, 21(8), 899-916. 
Julio César Torres-Rocha

Lin, A., \& Martin, P. W. (2005). Decolonisation, globalisation: Language-in-education policy and practice (Vol. 3). Clevedon, UK: Multilingual Matters.

Littlewood, W. (2007). Communicative and task-based language teaching in East Asian classrooms. Language Teaching, 40(3), 243-249.

Liu, Y., \& Xu, Y. (2011). Inclusion or exclusion? A narrative inquiry of a language teacher's identity experience in the 'new work order' of competing pedagogies. Teaching and Teacher Education, 27(3), 589-597.

Lorimer, C., \& Schulte, J. (2011). Reimagining TESOL professionalism: The graduate student perspective. CATESOL Journal, 23(1), 31-44.

Maley, A. (1992). An open letter to 'the profession' via the Editor of ELT Journal. ELT JournalVolume 46/1 January 1992 (C) Oxford University Press.

Maslow, A. (1998). Toward a psychology of being. New York: Wiley.

McKay, S. (2002). Teaching English as an International Language: Retbinking Goals and Approaches. Oxford: Oxford University Press.

Mignolo, W. (2009). Epistemic disobedience, independent thought and de-colonial freedom. Theory, Culture \& Society, 26(7-8), 1-23.

Ministerio de Educación Nacional de Colombia, MEN (2017). [Resolution 18583]. Retrieved from https://www.usbcali.edu.co/sites/default/files/ resolucion_final_18583_de_2017deroga_2041.pdf

Moncada, A. G. (2009). Professional development of EFL teachers in Colombia: Between colonial and local practices. Íkala, Revista de Lenguaje y Cultura, 12(1), 309-332.

Mora, A., Trejo, P., \& Roux, R. (2014). English language teachers' professional 174 development and identities. Profile: Issues in Teachers' Professional Development, 16(1), 49-62.

Nguyen, H. T. (2008). Conceptions of teaching by five Vietnamese American preservice teachers. Journal of Language, Identity, and Education, 7(2), 113-136.

Norton, B. (1997). Language, identity, and the ownership of English. TESOL Quarterly, 31(3), 409-429. 
EFL Teacher Professionalism and Identity: Between Local/Global ELT Tensions

Norton, B., \& Early, M. (2011). Researcher identity, narrative inquiry, and language teaching research. TESOL Quarterly, 45(3), 415-439.

Nunan, D. (1999). President's message: August/September 1999. TESOL Matters, 9 (4). Available at: http://www.tesol.org/s_tesol/sec_document. asp? $\mathrm{CID}=98 \& \mathrm{DID}=349$ (Accessed 28.10.2016).

Park, G. (2012). "I am never afraid of being recognized as an NNES": One teacher's journey in claiming and embracing her non-native speaker identity. TESOL Quarterly, 46(1), 127-151.

Pavlenko, A. (2003). "I never knew I was a bilingual": Reimagining teacher identities in TESOL. Journal of Language, Identity, and Education, 2(4), 251-268.

Pennycook, A. (2001). Critical applied linguistics: A critical introduction. New York, London Routledge.

Pennycook, A. (2010). Language as a local practice. New York: Routledge.

Phillipson, R. (1992). ELT: the native speaker's burden? ELT journal, 46(1), 12-18.

Phillipson, R. (2004). English in globalization: Three approaches. Journal of Language, Identity, and Education, 3(1), 73-84.

Richards, J. (2008). Second language teacher education today. RELC Journal, 39(2), 158-177.

Sachs, J. (2001) Teacher professional identity: Competing discourses, competing outcomes, Journal of Education Policy, 16(2), 149-161.

Sachs, J. (2003). Teacher professional standards: controlling or developing teaching? Teachers and Teaching: Theory and Practice, 9(2), 175-186.

Seidlhofer, B. (2005). English as a lingua franca. ELT Journal, 59(4), 330-339.

Sharifian, F. (2009). English as an International Language: Perspectives and Pedagogical Issues. Bristol: Multilingual Matters.

Singh, G., \& Richards, J. C. (2006). Teaching and learning in the language teacher education course room: A critical sociocultural perspective. RELC Journal, 37(2), 149-175. 
Julio César Torres-Rocha

Torres-Rocha, J. C. (2017). High School EFL Teachers' Identity and Their Emotions Towards Language Requirements. Profile: Issues in Teachers' Professional Development, 19(2), 41-55. https://doi.org/10.15446/profile.v19n2.60220

Tsui, A. (2007). Complexities of identity formation: A narrative inquiry of an EFL teacher. TESOL Quarterly, 41(4), 657-680.

Ubaque, D. F., \& Castañeda-Pena, H. (2017). Teacher research: Uncovering professional identities and trajectories of teacher researchers through narrative research-A Colombian case. International Education Studies, 10(3), 35. https://doi.org/10.5539/ies.v10n3p35

Varghese, M. (2011). Language teacher education and teacher identity. In F. M. Hult \& K. A. King (Eds.), Educational linguistics in practice: Applying the local globally and the global locally (pp. 16-26). Bristol, UK: Multilingual Matters.

Varghese, M., Morgan, B., Johnston, B., \& Johnson, K. A. (2005). Theorizing language teacher identity: Three perspectives and beyond. Journal of Language, Identity, and Education, 4(1), 21-44.

Wenger, E. (1998). Communities of practice: Learning as a social system. Systems Tbinker, 9(5), 1-23.

Wenger, E. (2010) Communities of practice and social learning systems: the career of a concept. In C. Blackmore (Ed.), Social Learning Systems and communities of practice (pp. 1-19). Milton Keynes: Springer Verlag and the Open University.

Whitty, G. (2006). Teacher professionalism in a new era. First General Teacbing Council for Northern Ireland Annual Lecture, Belfast, 3, 2006.

Wilson, A., Akerlind, G., Walsh, B., Stevens, B., Turner, B., \& Shield, A. (2013). 176 Making 'professionalism' meaningful to students in higher education. Studies in Higher Education, 38(8), 1222-1238. 